\title{
Ecological and Developmental Aspects of Multi-Stemmed Clusters of Siberian Spruce (Picea obovata Ledeb.) in the Southern Urals
}

\author{
Nadezhda Devi*
}

\author{
Vos'mogo Marta Str., 202, Ekaterinburg, 620144 Russia / Department of Dendrochronology, Institute of Plant and \\ Animal Ecology, Ural Division, Russian Academy of Sciences, Russia
}

\begin{abstract}
The tree-line ecotone in the Southern Urals is mostly formed by monospecific stands of Siberian spruce (Picea obovata Ledeb.). Spruce is an ecologically plastic, cold-tolerant species that presents various growth forms. Moreover, its growth is further affected by stressful environment factors, including low temperatures, snowless winters, and strong winds. Thus, the morphological variability of individual trees can be due to climate-driven transformations, and represents a manifestation of biological plasticity. It was found that multi-stemmed clusters were formed by the rooting of groundlevel branches of formerly single-stemmed trees. Age analysis performed for 771 samples taken from 70 tree clusters demonstrated that mass rooting of branches started in the beginning of the 20th century and is ongoing. Dendroclimatic analysis did not demonstrate any significant links between the dynamics of stem formation and climatic data. The average biological age of mass rooting coincides with the period at which soil nutrition would have declined severely and the main root system would have become non-functional. This research shows that dendrochronological research can be used to help understand the ecophysiology of plants.
\end{abstract}

Keywords: Multi-stemmed clusters, Siberian spruce, Southern Urals.

\section{INTRODUCTION}

The tree-line ecotone in the Southern Ural Mountains is the transition zone across which forests grade into tundra ecosystems [1]. Within this ecotone the precise location and structure of timberline can be influenced by various physical factors besides low temperatures. These factors include topography, substrate, quantity and distribution of snow and wind [2-4]. Trees within this ecotone demonstrate speciesspecific response to these physical factors. The most widespread adaptation is a change in growth form of individual trees [5-9].

Siberian spruce (Picea obovata Ledeb.) has been widely used to reconstruct past climates throught correlations of tree-ring widths with climate data [10]. There are also published reports on its productivity $[11,12]$ and on the effects of climate on regeneration dynamics [13]. A chronology of extreme climatic events over the past two hundred years has recently been constructed, using frost and light rings (M. Gurskaya, unpublished data). In contrast to the growth of individual trees, however, little is known about the impact of climatic changes on its growth forms and growth strategies. It takes on a multi-stemmed formed near treeline (Fig. 1), and there is currently no mechanistic understanding of the development of this growth form.

*Address correspondence to this author at the Vos'mogo Marta Str., 202, Ekaterinburg, 620144 Russia / Department of Dendrochronology, Institute of Plant and Animal Ecology, Ural Division, Russian Academy of Sciences, Russia; Tel: +7(343) 2103858 (+207); Fax: +7(343) 260-82-55;

E-mails: nadya@ipae.uran.ru,nele_2000@rambler.ru
This study was undertaken to fill these gaps. The research was designed to help understand whether these tree clusters originate from a common tree, and if so, to learn the mechanism and speed of tree cluster formation, and the extent to which climate has driven the growth form change. The specific objectives include:

1. Identification of the mechanisms by which multistemmed clusters form.

2. Determination of the timeline for tree establishment and for change in growth form.

3. Examination of whether the establishment date and growth form change were driven by observed climatic change.

\section{MATERIALS AND METHODS}

The study was performed in the Southern Ural Mountains, Russia $\left(54^{\circ} 30^{\prime} \mathrm{N}, 58^{\circ} 49^{\prime} \mathrm{E}\right)$ at the southwestern slope of the Iremel massif. The climate of the Iremel mountain region is continental, as demonstrated by the large annual temperature amplitude of over $30^{\circ} \mathrm{C}$.

The treeline ecotone in this zone extends from 1255 to $1360 \mathrm{~m}$ a.s.l. and is dominated by Siberian spruce (Picea obovata Ledeb.) in association with mountain birch (Betula tortuosa Ledeb.) [14].

We established three $20 \mathrm{~m} \times 20 \mathrm{~m}$ plots in four typical categories of the forest-tundra ecotone [15]: tundra with isolated trees (treeline; $>50 \mathrm{~m}$ between neighboring trees); sparse tree growth (20-50 m between trees); open forest (7$20 \mathrm{~m}$ between the trees), and closed forest $(<7 \mathrm{~m}$ between 
trees). In each of the plots, all trees and saplings taller than $20 \mathrm{~cm}$ were counted and basic morphometric parameters such as growth form, tree height, stem diameter, crown length, and density as well as the mean distances between trees were recorded. In order to determine when multistemmed trees were appeared, we took samples of 70 clusters at the plots along the transect (20 in tundra with isolated trees, 30 in sparse three growth and open forest and 20 in closed forest). Model trees were dug up to determine the origin of the derived trunks. Tree or shoot age was assessed from either one stem disc or one tree core made at the base of each stem, at the base of the tap root of each individual and at the nodes of the rooting of branches using standard dendrochronological methods [16-18]. To evaluate climate-growth relationship we calculated coefficients of correlations (r) between tree appearance, periods of derivative stems formation and four climatic variables (winter temperature, summer temperature, winter precipitation and summer precipitation).

\section{RESULTS AND DISCUSSION}

The multi-stemmed trees, or tree clusters had more than one stem growing from a single root mass (Fig. 1). These trees have a fused base area that shows multiple piths at ground level. The tree clusters studied here had up to 32 stems per individual cluster.

Studied clusters appeared to have formed by rooting of the ground-level branches of previously single-stemmed trees. In the first 5-10 years after germination, the root system was dominated by the main root. Within the third year, adventives roots formed on the original aboveground axis (the trunk) and on the branches. Formation and growth of the roots were associated with a decrease in functional significance, growth weakening and decline of the main root system, as evidenced by the dendrochronological analysis of main root remnants. By the age of 15-20 years the main root completely dies and evidently the acquisition soil nutrients and water appeared to have been transferred entirely to the adventitious root system [19]. These results suggest the following scenario: as old roots grow into the deeper soil layers, they encounter soil of a higher density and with decreased aeration. Root growth then slows and the roots gradually die. They are replaced by new roots, formed from dormant buds on the lower side of the tree branches. Dormant buds on lateral branches of the trees are activated as a result of changes in light intensity and humidity. Rooted branches grow as orthotropic stems and form the multistemmed clusters.

Multi-stemmed trees of the tundra had 2.3 to 3.3 times the stem diameter and/or height of single-stemmed trees of the closed forest. For all tree stands the height to diameter relationship for stems is curvilinear, with the coefficient of determination varying from 0.588 to 0.841 (data not shown). This curvilinearity probably is due to the presence of competitive relations within multiple clusters that violates rules for constant ratio of tree diameter to height. Most likely, these trunks located within a cluster develop under low light and low wind, causing increased height to diameter growth (data not shown). The cluster may improve temperature relations for the tree, as well, but increasing the boundary layer and helping the tree trap heat.

The age structure analyses is shown in Table 1. At the highest elevation sites of the present-day ecotone (open, near treeline), the mean age for multi-stemmed trees is 70 years. In lower part of the ecotone (closed forest), mean age is about 115 years. Because of the low temperatures, when trees die they are detectable for many decades thereafter. The

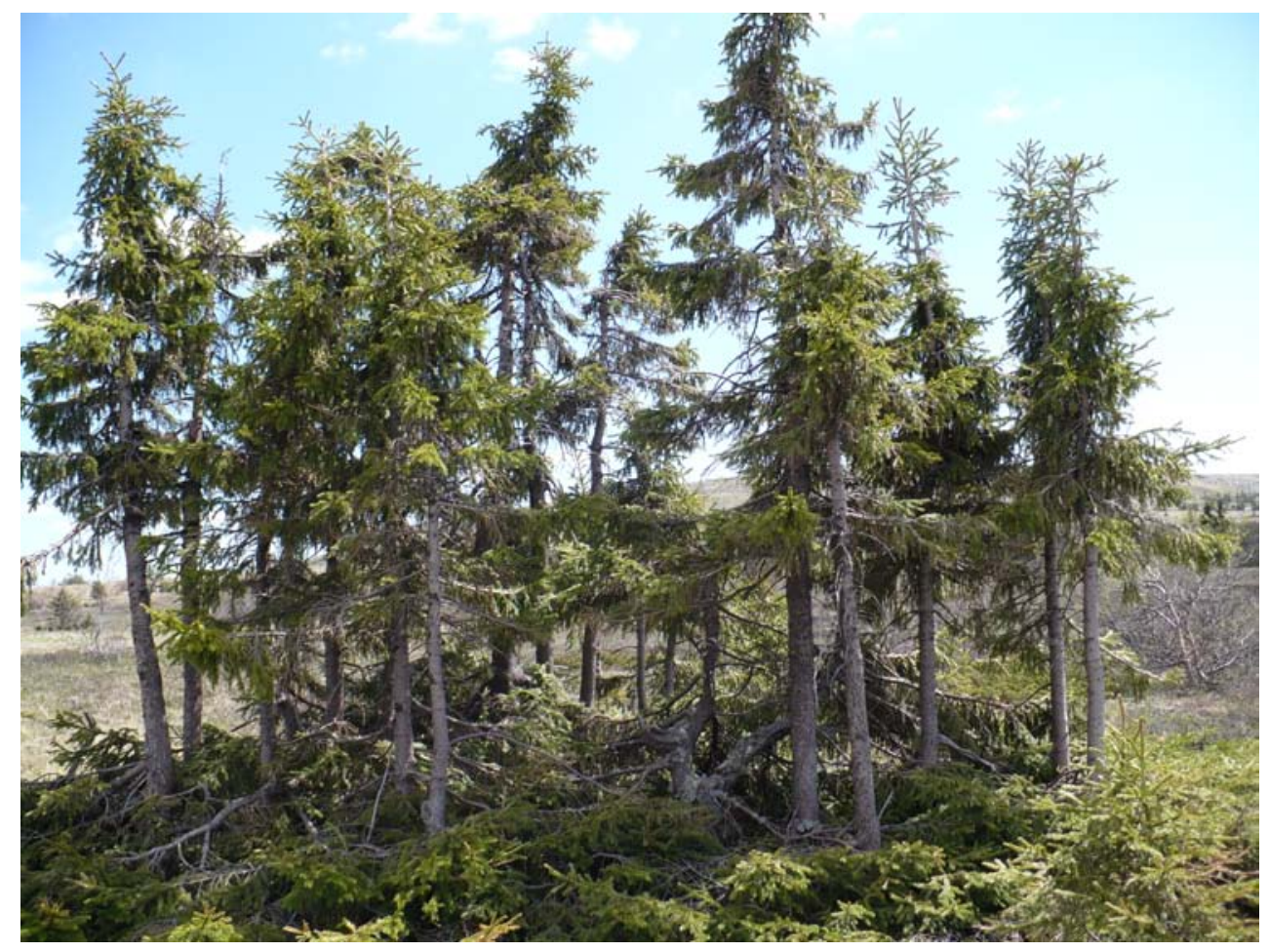

Fig. (1). One tree of Siberian spruce (Picea obovata Ledeb.) that has the multi-stemmed cluster growth form. 
Table 1. Time and Number of Multi-Stemmed Clusters and its Stems, Established in Different Tree Stands

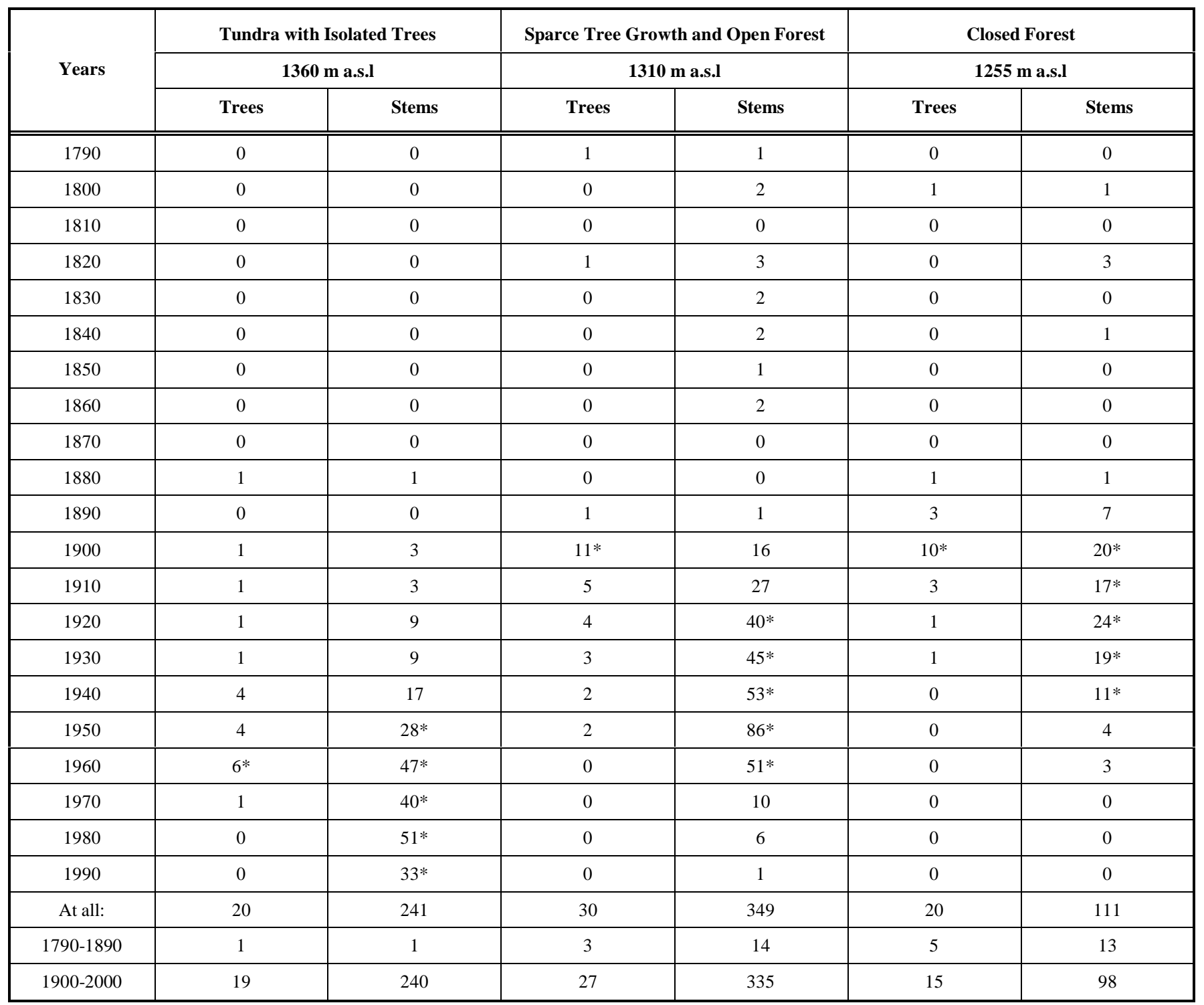

*- Periods of mass tree appearance and side stem formation

lack of dead trees and the tree-ring data show that there were almost no live trees at the current tree-line until 1900, but that after that date the forests have rapidly expanded upward. This is also confirmed by a comparison of the current ecotone with historic photographs from 1920s.

Moiseev et al. (2004) observed that upward expansion of Siberian spruce forests is related to increased winter precipitation. The analyses presented here show that upward expansion was accompanied by significant changes in tree growth forms (Table 1). The frequent formation of side stems began in the early twentieth century, and continues at present. The tree-ring analyses (Table 1) show that the derivative vertical stems of the multi-stemmed spruce trees emerged within a relatively short period, from about 1910 until the 1940s in closed forest, from about 1910 to the 1950s in open forest, and from about 1960 to the 1990s in the isolated trees within the tundra. Dendroclimatic analysis did not demonstrate any significant links between stem formation and climatic data (Table 2).
Table 2. Relationship Between Tree Appearances, Periods of Derivative Stems Formation and Climate. Coefficients of Correlation (r) were Calculated for a Decadal Time Scale. Winter was from November to March; Summer was from June to August

\begin{tabular}{|c|c|c|}
\hline Climate Variables & $\begin{array}{c}\text { Tree } \\
\text { Appearance } \\
\mathbf{n = 1 7}\end{array}$ & $\begin{array}{c}\text { Periods of Derivative } \\
\text { Stems Formation } \\
\mathbf{n = 1 7}\end{array}$ \\
\hline \hline Winter temperature & $-0,27$ & 0,38 \\
\hline Summer temperature & $-0,19$ & 0,32 \\
\hline Winter precipitation & 0,22 & 0,025 \\
\hline Summer precipitation & $-0,014$ & 0,25 \\
\hline
\end{tabular}

$\mathrm{P}<0.05$.

The derived stems, those that developed from mass rooting of ground level branches (Fig. 2), varied in age from 10 to 40 years for $65-81 \%$ of all cases. Unlike the original 


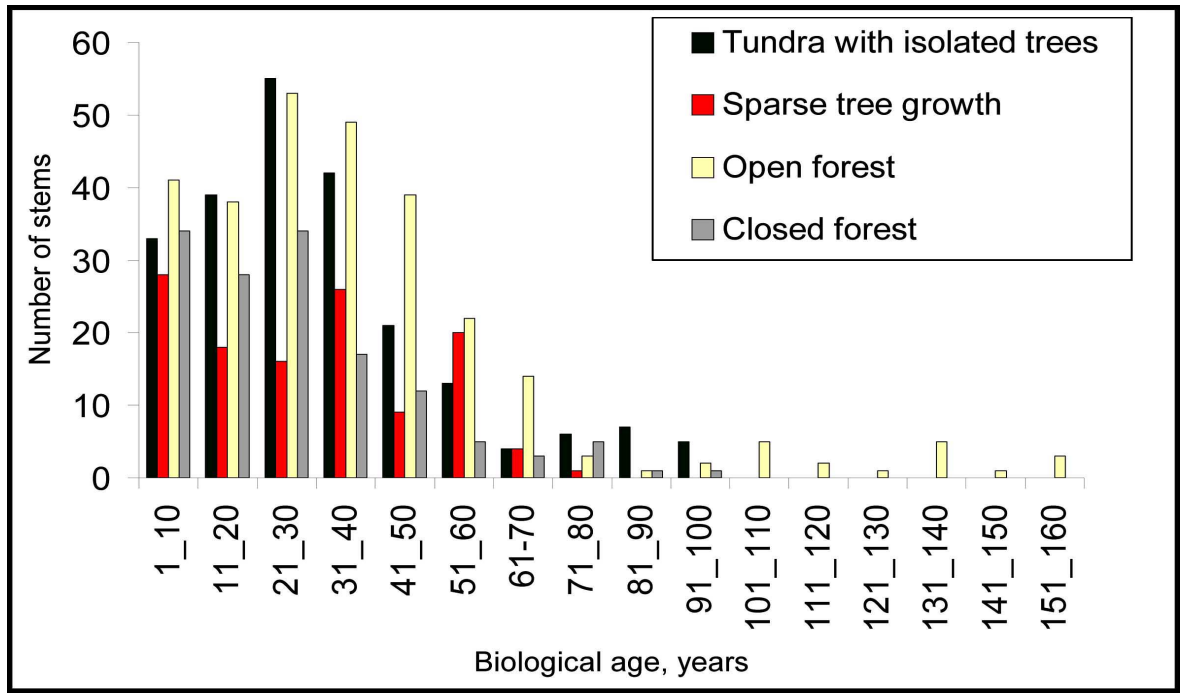

Fig. (2). Biological age of the side stems within multi-stemmed clusters of Siberian spruce (Picea obovata Ledeb.).

tree stems (Table 1), the establishment of these derivative stems is independent of calendar period and forest category. The timing of the derived stems appears to coincide with the time at which the plants would have increasing difficulty getting nutrients because their main root system would have died. Thus, it is possible that a signal related to poor nutrient and/or water status is triggering the formation of roots in the branches.

The data suggest that by the time the original stem is 90 to 100 years old, it can no longer develop these adventitious roots and can no longer develop daughter stems. But the clusters could continue to grow outward by rooting of the lower branches of derivative stems.

In conclusion, there is evidence that the tree-line has been expanding upwards, during the last century by about $100 \mathrm{~m}$ in altitude. This shift was accompanied by changes in tree growth forms, but this phenomenon was not linked to climate change. Clusters of multiple-stemmed Siberian spruce trees near tree-line are formed from rooted branches of an original single-stemmed tree. The stems can grow wider and taller than can single-stemmed trees. It appears that after the original root system of single stemmed trees becomes relatively ineffective at nutrient and water uptake, the adventives root system forms. The incipient rooting of branches led to multi-stemmed cluster formation. Future work in this system could collect data to test this interpretation. The multi-stemmed form appears to allow trees to survive by exploiting nearby soil resources. The larger stems within these clusters suggest there is a growth advantage to sheltering the young developing shoots, and possibly of changing the microclimate around the trees such as by decreasing wind and increasing temperature. This work demonstrates the use of dendrochronologic techniques to better understand the process of tree adaptations in the climatically-vulnerable tree-line region of the Southern Urals.

\section{CONFLICT OF INTEREST}

The author confirms that this article content has no conflict of interest.

\section{ACKNOWLEDGMENTS}

This work was supported by the Russian Foundation for Basic Research, project no. 12-04-31048 and by the project of the Ural Branch of the Russian Academy of Sciences no. 12-c-4-1038.

\section{REFERENCES}

[1] Shiyatov SG. Dendrochronology of the tree-line at the Urals. Moskow: Nauka 1986.

[2] Körner C. A re-assessment of high elevation treeline positions and their explanation. Oecologia 1998; 115: 445-59.

[3] Körner C. Alpine plant life: functional plant ecology of high mountain ecosystems. Berlin: Springer 1999.

[4] Holtmeier F-K. Mountain timberlines: ecology, patchiness, and dynamics. Dordrecht: Kluwer 2003.

[5] Gorchakovskiy PL, Shiyatov SG. Phytoindication of the environmental conditions and natural processes in the alpine terrain. Moskow: Nauka 1985.

[6] Weisberg PJ, Baker WL. Spatial variation in tree seedling and krummholz growth in the forest-tundra ecotone of Rocky Mountain National Park, Colorado, USA. Arctic Alpine Res 1995; 27: 11629.

[7] Pereg D, Payette S. Development of black spruce growth forms at tree-line. Plant Ecol 1998; 138: 137-47.

[8] Goroshkevich SN, Kustova EA. Morphogenesis of the creeping life form of Siberian cedar at the upper limit of proliferation in West Sayan mountains. Russian J Ecol 2002; 4: 243-9.

[9] Devi N, Hagedorn F, Moiseev P, et al. Expanding forests and changing growth forms of Siberian larch at the Polar Urals treeline during the 20th century. Glob Chang Biol 2008; 14: 1581-91.

[10] Moiseev PA, Van der Meer M, Rigling A, Shevchenko IG. Effect of climatic changes on the formation of Siberian spruce generations in subgoltsy tree stands of the Southern Urals. Russian J Ecol 2004; 35: $135-43$.

[11] Babenko TS, Nagimov ZJ, Moiseev PA. Peculiarities of Siberian spruce growth on the upper limit of its distribution (Southern Urals, massif Iremel). Russian J Ecol 2008; 1: 65-9.

[12] Nagimov ZJ, Babenko TS, Shevchenko IG, Rahmanov IV, Moiseev PA. Peculiarities of growth and phytomass formation in spruce stands in the Southern Ural mountains (by the example of Malyj Iremel Mountain). Conifers of the Boreal Zone 2007; 4: 42730 .

[13] Koshkina NB, Moiseev PA, Goryaeva AV. Germination of Siberian spruce in the tree-line ecotone on Iremel Massif. Russian J Ecol 2008; 2: 93-102.

[14] Tsvetaev AA. Mountains Iremel (Southern Ural). Ufa 1960. 
[15] Shiyatov SG, Terent'ev MM, Fomin VV. Spatiotemporal dynamics of forest-tundra communities in the Polar Urals. Russian J Ecol 2005; 36: 69-75

[16] Fritts HC. Tree rings and climate. London; New York; San Francisco: Academy Press 1976.
[17] Cook ER, Kairiukstis LA, Eds. Methods of Dendrochronology: Applications in the Environmental Sciences. Dordrecht; Boston; London: Kluwer Acad Pub 1990.

[18] Shiyatov SG, Vaganov EA, Kirdyanov AV, et al. Methods of Dendrochronology. Krasnoyarsk: KrasGU 2000.

[19] Serebryakov IG. Ecological morphology of plants. Moskow: Vysshaya Shkola 1962.

Received: March 19, 2013

Revised: September 24, 2013

Accepted: October 31, 2013

(C) Nadezhda Devi; Licensee Bentham Open.

This is an open access article licensed under the terms of the Creative Commons Attribution Non-Commercial License (http://creativecommons.org/licenses/by$\mathrm{nc} / 3.0 /$ ) which permits unrestricted, non-commercial use, distribution and reproduction in any medium, provided the work is properly cited. 